\title{
Graduate attributes in computing disciplines desirable to prepare graduates for entry into computing profession in Nigeria
}

\author{
Bashiru Lawal 1, ${ }^{*}$, Aliyu S. Rafi Anka ${ }^{1}$, Bashir Idris ${ }^{1}$, Tijani Salihu ${ }^{2}$ and Hussaini Aliyu ${ }^{3}$ \\ ${ }^{1}$ Department of Computer Science, Federal College of Education (Technical) Gusau - Nigeria. \\ ${ }^{2}$ Department of Mathematics, Federal College of Education (Technical) Gusau - Nigeria. \\ ${ }^{3}$ Department of English Language, Federal College of Education (Technical) Gusau - Nigeria.
}

Global Journal of Engineering and Technology Advances, 2021, 08(01), 010-018

Publication history: Received on 01 June 2021; revised on 04 July 2021; accepted on 07 July 2021

Article DOI: https://doi.org/10.30574/gjeta.2021.8.1.0096

\begin{abstract}
The purpose of this study was to identify the important graduate attributes in computing disciplines perceived by lecturers of the three sectors of Nigerian Higher Education Institutions (HEIs) desirable for entry into computing profession in Nigeria. The descriptive survey research design was adopted. Fifty (50) academic staff of computer related disciplines from each of the HEIs sectors (Universities, Polytechnics and Colleges of Education) in the NorthCentral Nigeria were screened and used through convenience random and purposive sampling methods. The Computing Disciplines' Graduate Attributes Scale (CDGAS) $(r=0.82)$ was the research instrument used in gleaning the field data. Four research questions were raised and one hypothesis formulated, tested and analyzed using Analysis of Variance (ANOVA) statistical package. The findings identified 13, 17 and 16 important graduate attributes desirable to prepare graduates from Nigerian Universities, Polytechnic and Colleges of Educations (COEs) respectively for entry into computing profession. Common amongst the identified graduate attributes are: collaboration and teamwork, lifelong learning skills, cognitive ability and practical skills, effective communication skills and leadership quality. Also, result from hypothesis testing showed a significant relationship amongst the identified graduate attributes in computing discipline in all sectors of HIEs in Nigeria. ( $F=0.610$; Critical Value $=3.12 ; \mathrm{P}<0.05$ ). Conclusively, the study recommended that career development support efforts should be included in the curriculum, which will focus on helping prospective graduate in computing related discipline on their academic abilities, personal qualities and skills.
\end{abstract}

Keywords: Computing Disciplines; Computing Profession; Graduate Attributes; Higher Education Institutions

\section{Introduction}

Graduate attributes "encompass values, attitudes, critical thinking, ethical and professional behaviour, and the capacity of a graduate to take what has been learnt beyond the site of learning" [4]. In other words, they are attributes, which are oriented towards knowledge, skills and competences that are required of graduates to practice at their working career. They are also focus of Higher Education Institutions' wide curriculum renewal [6].

Computing on the other hand is any activity that uses computers to manage, process, and communicate information. It includes development of both hardware and software. Computing is a critical, integral component of modern industrial technology [1]. However, Computing disciplines, defined jointly by the ACM (Association for Computing Machinery) and IEEE (Institute of Electrical and Electronic Engineers) Computer Society are: computer science (CS); information technology (IT); information systems (IS); software engineering (SE); and computer engineering (CE) [3]. Thus, in reality there is not a single computing discipline but at least five. Including different sub-specialities, there are dozens of possible computing educational paths for prospective students.

*Corresponding author: Bashiru Lawal; E-Mail: blawal3119@gmail.com, bash3119@yahoo.com

Department of Computer Science, Federal College of Education (Technical) Gusau - Nigeria. 
The field of computing has expanded rapidly over the past ten years, and after surveying the three sectors of the Nigerian HEIs that offer computing programmes, we realized that, majority of the HEIs surveyed do not have a clear, succinct statements of graduate attributes and competency profiles that are expected of their graduates of computing discipline. Also, a critical analysis of findings of our survey of the Nigerian HEIs sectors show that prospective graduates in computing discipline and their career counsellors are ignorance of skills a graduate of computing discipline must have to be able to function in the fast changing computing environment of the 21 st century and the knowledge-base that is required to give the graduate the edge to excel in a working career [2].

However, a literature review (e.g. [4]) conducted on graduateness and graduate attributes in computing discipline reveal that, identification of appropriate graduate attributes in computing disciplines and their adoption across programmes has been seen as a way to address these problems. In order words, if computing departments and their students are adequately informed about important graduate attributes a graduate of computing discipline must have to be able to function as a professional in the fast changing computing environment of the 21st century, there is a good chance graduate of computer related courses will acquire competence to practise at the appropriate level as professional and have the edge to excel in their profession.

\subsection{Background to the Study}

Computing as a discipline was adopted by some Nigerian Universities only in the early 1990s, many years after computing was an established discipline in the United States of America (USA)[7]. [7] observed that only a handful of countries in Sub Saharan Africa such as Nigeria, Malawi and Zimbabwe have universities that offer computer science degrees [7]. In the USA such programmes emerged in the 1960s [3]. The first and still the most popular of the computing disciplines to be adopted in Nigeria was computer science (CS), which was in most cases initially hosted in the mathematics units of the institutions, with mathematicians delivering most of the modules of these CS programmes. As capacity building for CS trainers became necessary, graduates of mathematics trained at MSc or PhD level in disciplines related to CS. Obviously, those who did not train in CS at the undergraduate level lacked aspects of CS foundation and thus could not competently undertake the research required by higher degrees in CS [5]

A computer professional is anyone who has undergone one form of professional or formal training or the other on computer [9]. Such formal training includes certificate, diploma or degree in computing. These categories of people are involved development, maintenance, and usage of computers. These phenomenon pop different career opportunities associated with computer usage. These career opportunities are: Computer Manager, System Analyst, Programmers, Computer Educators, Computer Engineers and Technicians, and Computer Operators [9]. The development of a computing professional in Nigeria is a continuous learning process. The first stage may be the attainment of an accredited educational qualification, the graduate stage. The second stage, following a period of training and experience, may lead to professional registration, licensure, or some other professional recognition, depending on the professional body or jurisdiction [5].

In addition, computing professionals are expected to engage in life-long learning in order to maintain and enhance competency throughout their working lives. Because of the universally essential nature of computer applications and its critical, integral component of modern industrial technology, there is a real need to identify attributes, which are clear, succinct statements of the expected personal qualities, academic capabilities and skills that are required of graduates in computing. This will give a path way to adequately prepare graduates for entry into a computing profession based on generally recognized knowledge and abilities across board.

Toward this end, this research intends to identify the important graduate attributes that are perceived by academics in the Nigerian HEIs as the basic academic abilities, personal qualities and skills which computing graduates must have at the exit level of the qualification as computer professional, be it a degree or diploma. The study argues that identifying the most important graduate attributes in computer related discipline across the three sectors of the Nigerian HEIs will provide insights that will enhance the HEIs to boost the professionalism prospects of graduates of computing discipline in Nigeria.

\subsection{Statement of the Problem}

In the Nigerian HEIs sectors, the issue of graduate attributes has received considerable attention as new and oldest generations higher institutions seek to articulate their purposes and demonstrate their accountability with regard to the successful graduation of students. In the case of universities and career focussed higher education (such as Colleges of Education), there are concerns around graduate unemployment and the alleged mismatch between graduates and the needs of the private and public sectors. There are apparently no any defined attributes guiding the offered programmes, which graduates are expected to attain at exit point. Specifically, Nigerian HEIs offering computing 
disciplines do not explicitly have clear, succinct statements of the expected capability, qualified if necessary by a range indication appropriate to the type of programme. However, researches (e.g. [4]), show that identification of appropriate graduate attributes in computing disciplines and their adoption across programmes has been seen as a way to address these concerns. This is the problem the study intends to address.

\subsection{Purpose of the Study}

The main objective of this study is to identify the graduate attributes in computing discipline that are perceived as most important by academics of Nigerian HEIs to give graduates in computer related disciplines the edge to excel in their working career. Other sub objectives designed to guide the study are:

- Identify the graduate attributes in computing disciplines' that are perceived as most important by academics of Nigerian Universities to adequately prepare Nigerian University graduates for entry into a computing profession.

- Identify the graduate attributes in computing disciplines' that are perceived as most important by academics of Nigerian Polytechnics to adequately prepare Nigerian Polytechnic graduates for entry into a computing profession.

- Identify the graduate attributes in computing disciplines' that are perceived as most important by academics of Colleges of Education (COE) in Nigerian to adequately prepare Nigerian COE graduates for entry into a computing profession.

- Determine the relationship between the graduate attributes determinant for entry into a computing profession across the three sectors of the Nigerian HEIs.

\subsection{Research Questions}

The following research questions were raised to guide the study:

- What graduate attributes in computing discipline do academics of Nigerian Universities consider desirable to prepare graduates for entry into a computing profession

- What graduate attributes in computing discipline do academics of Nigerian Polytechnics consider desirable to prepare graduates for entry into a computing profession

- What graduate attributes in computing discipline do academics of Nigerian COEs consider desirable to prepare graduates for entry into a computing profession

- Is there any difference in the graduate attributes desirable for computing profession across the three sectors of HEIs in Nigeria?

\section{Hypothesis}

The null hypothesis formulated and tested at 0.05 for the research is:

Ho: There is no significant difference between the computing discipline graduates attributes desirable for entry into computing profession across the Nigerian HEIs

\section{Methodology}

The study adopted descriptive survey design. The population for the study comprised of all academic staff of computer related discipline in all the three sectors of HEIs across the North-Western region of Nigeria. A combined sampling technique comprising: stratified, convenience and purposive sampling was adopted and used to draw a sample of 18 HEIs out of the available $41 \mathrm{HEIs}$ and 180 respondents were selected from the sampled HEIs across the study zone. The instruments used for data collection was a 20 - item questionnaire. The instrument was face validated by three research experts from three different HEIs from the region of study. The reliability of the instruments was determined using Cronbach Alpha and a reliable coefficient of 0.89 obtained. The researchers personally administered the instruments (questionnaires) on the selected sample to elicit the relevant information needed for the study. 150 out of the 180 administered questionnaires were correctly filled and returned giving a return rate of $83.33 \%$. 
Four research questions were raised and one hypothesis tested at 0.05 level of significance. The data collected were analysed using the Mean and ANOVA statistical analysis packages. The Mean statistic was used to answer the research questions while hypothesis was tested at 0.05 level of significance using ANOVA. Regarding the decision rule, any questionnaire item with a mean value of 2.50 or above was interpreted as desirable response of such item while a mean score below 2.50 indicates a non-desirable response for the item.

\subsection{Research Question 1}

What graduate attributes in computing disciplines do academics of Nigerian Universities consider desirable to prepare graduates for entry into a computing profession

Table 1 Perceptions of Nigerian Universities' lecturers on the graduate attributes in computing disciplines desirable for entry into a computing profession in Nigeria.

\begin{tabular}{|c|c|c|c|c|c|c|}
\hline $\mathbf{S} / \mathbf{N}$ & Graduate Attributes & $\mathbf{F}$ & $\mathbf{N}$ & Mean & S.D & Decision \\
\hline 1 & $\begin{array}{l}\text { Communication effectively using visual, mathematical and } \\
\text { or language skills }\end{array}$ & 39 & 50 & 3.521 & 1.554 & Desirable \\
\hline 2 & $\begin{array}{l}\text { Using and displaying creative thinking for responsible } \\
\text { problem solving }\end{array}$ & 39 & 10 & 3.522 & 1.498 & Desirable \\
\hline 3 & Creativity and innovative thinking & 39 & 50 & 3.522 & 1.501 & Desirable \\
\hline 4 & Leadership quality, collaboration and teamwork & 46 & 50 & 4.655 & 1.532 & Desirable \\
\hline 5 & $\begin{array}{l}\text { Cognitive ability and skills in practical skills relating } \\
\text { tosolution of mathematical problems and its application }\end{array}$ & 40 & 50 & 3.548 & 1.550 & Desirable \\
\hline 6 & Lifelong learning skills & 33 & 50 & 3.321 & 1.500 & Desirable \\
\hline 7 & $\begin{array}{l}\text { Self-management of learning development, time and } \\
\text { organizational skills }\end{array}$ & 29 & 50 & 3.012 & 1.498 & Desirable \\
\hline 8 & Teaching skills & 23 & 50 & 2.259 & 1.399 & Low \\
\hline 9 & $\begin{array}{l}\text { Ability to apply knowledge to solving theoretical and } \\
\text { practical problems in other related area in relation to } \\
\text { national and societal needs }\end{array}$ & 33 & 50 & 3.321 & 1.501 & Desirable \\
\hline 10 & Adaptability and flexibility & 18 & 50 & 1.002 & 1.488 & Low \\
\hline 11 & Internet surfing skills & 23 & 50 & 2.259 & 1.399 & Low \\
\hline 12 & Research skills & 29 & 50 & 3.116 & 1.499 & Desirable \\
\hline 13 & $\begin{array}{l}\text { Attention to rigorous thinking: knowledge and } \\
\text { understanding of modelling and design }\end{array}$ & 33 & 50 & 3.321 & 1.500 & Desirable \\
\hline 14 & $\begin{array}{l}\text { Programming Proficiency in several programming } \\
\text { languages }\end{array}$ & 33 & 50 & 3.321 & 1.497 & Moderate \\
\hline 15 & Analytical thinking & 21 & 50 & 2.001 & 1.490 & Low \\
\hline 16 & Resilient in the face of obstacles & 23 & 50 & 2.228 & 1.451 & Low \\
\hline 17 & I Interpersonal skills & 21 & 50 & 2.003 & 1.497 & Desirable \\
\hline 18 & Organizational skills & 33 & 50 & 3.321 & 1.497 & Desirable \\
\hline 19 & Developing entrepreneurial opportunities & 20 & 50 & 2.106 & 1.498 & Desirable \\
\hline 20 & Capacity to business orientation & 24 & 50 & 2.558 & 1.446 & Moderate \\
\hline 21 & Capacity to future focused & 24 & 50 & 2.558 & 1.447 & Moderate \\
\hline 22 & User focused & 19 & 50 & $1 . .921$ & 1.440 & Low \\
\hline 23 & Attainment to engineering principles & 20 & 50 & 2.130 & 1.498 & Low \\
\hline 24 & Proficiency in social media application & 20 & 50 & 2.130 & 1.427 & Low \\
\hline 25 & Critical evaluation and testing & 25 & 50 & 2.729 & 1.465 & Moderate \\
\hline
\end{tabular}


Table 1 presents the perceptions of Nigerian Universities' lecturers on graduate attributes in computing disciplines desirable for entry into a computing profession in Nigeria.

Analysis of result data presented in the Table 1 showed that 12 out of the 25 listed graduate attributes are considered desirable for entry into computing profession in Nigeria. Also, analysis of the result revealed that lecturers in the Nigerian Universities attributed high level desirability to graduate attributes: Leadership quality, collaboration and teamwork for entry into computer profession Mean \& SD scores of 4.5655 and 1.532 respectively for entry into computing profession.

Other graduate attributes that were perceived to be more desirable for computing profession are: Cognitive ability and skills in practical skills relating to solution of mathematical problems and its application (3.548 \& 1.550$)$; Communication effectively using visual, mathematical and or language skills (3.521 \& 1.554); and others. However, the graduate attribute: adaptability and flexibility $(M=1.002 \& S . D=1.488)$ is considered least desirable for entry into computing profession by the universities computing lectures.

\subsection{Research Question 2}

What graduate attributes in computing disciplines do b academics of Nigerian Polytechnic consider desirable to prepare graduates for entry into computing profession.

Table 2 presents the perceptions of Nigerian Polytechnic lecturers on graduate attributes in computing disciplines desirable for entry into a computing profession.

Table 2 Perceptions of Nigerian Polytechnic lecturers on the graduate attributes in computing disciplines desirable for entry into computing profession

\begin{tabular}{|c|c|c|c|c|c|c|}
\hline $\mathbf{S} / \mathbf{N}$ & Graduate Attributes & $\mathbf{F}$ & $\mathbf{N}$ & Mean & S.D & Decision \\
\hline 1 & $\begin{array}{l}\text { Communication effectively using visual, } \\
\text { mathematical and or language skills }\end{array}$ & 37 & 50 & 3.561 & 1.554 & Desirable \\
\hline 2 & $\begin{array}{l}\text { Using and displaying creative thinking for } \\
\text { responsible problem solving }\end{array}$ & 33 & 50 & 3.221 & 1.498 & Desirable \\
\hline 3 & Creativity and innovative thinking & 39 & 50 & 3.531 & 1.501 & Desirable \\
\hline 4 & Leadership quality, collaboration and teamwork & 41 & 50 & 3.955 & 1.552 & Desirable \\
\hline 5 & $\begin{array}{l}\text { Cognitive ability and skills in practical skills } \\
\text { relating to solution of mathematical problems and } \\
\text { its application }\end{array}$ & 40 & 50 & 4.048 & 1.550 & Desirable \\
\hline 6 & Lifelong learning skills & 33 & 50 & 3.321 & 1.500 & Desirable \\
\hline 7 & $\begin{array}{l}\text { Self-management of learning development, time and } \\
\text { organizational skills }\end{array}$ & 22 & 50 & 3.012 & 1.498 & Desirable \\
\hline 8 & Teaching skills & 23 & 50 & 2.259 & 1.399 & Low \\
\hline 9 & $\begin{array}{l}\text { Ability to apply knowledge to solving theoretical } \\
\text { and practical problems in other related area in } \\
\text { relation to national and societal needs }\end{array}$ & 43 & 50 & 4.321 & 1.501 & Desirable \\
\hline 10 & Adaptability and flexibility & 13 & 50 & 1.010 & 1.642 & Low \\
\hline 11 & Internet surfing skills & 16 & 50 & 1459 & 1.399 & Low \\
\hline 12 & Research skills & 29 & 50 & 3.016 & 1.499 & Desirable \\
\hline 13 & $\begin{array}{l}\text { Attention to rigorous thinking: knowledge and } \\
\text { understanding of modelling and design }\end{array}$ & 33 & 50 & 3.321 & 1.500 & Desirable \\
\hline 14 & $\begin{array}{l}\text { Programming Proficiency in several programming } \\
\text { languages }\end{array}$ & 40 & 50 & 4.048 & 1.550 & Desirable \\
\hline
\end{tabular}




\begin{tabular}{|c|l|c|c|c|c|c|}
\hline 15 & Analytical thinking & 29 & 50 & 3.006 & 1.490 & Desirable \\
\hline 16 & Resilient in the face of obstacles & 31 & 50 & 3.211 & 1.451 & Low \\
\hline 17 & I Interpersonal skills & 30 & 50 & 3.013 & 1.297 & Desirable \\
\hline 18 & Organizational skills & 30 & 50 & 3.011 & 1.497 & Desirable \\
\hline 19 & Developing entrepreneurial opportunities & 29 & 50 & 3.006 & 1.498 & Desirable \\
\hline 20 & Capacity to business orientation & 29 & 50 & 3.006 & 1.496 & Desirable \\
\hline 21 & Capacity to future focused & 25 & 50 & 2.48 & 1.447 & Moderate \\
\hline 22 & User focused & 13 & 50 & 1.010 & 1.640 & Low \\
\hline 23 & Attainment to engineering principles & 39 & 50 & 3.533 & 1.498 & Desirable \\
\hline 24 & Proficiency in social media application & 16 & 50 & 1.230 & 1.427 & Low \\
\hline 25 & Critical evaluation and testing & 21 & 50 & 2.29 & 1.465 & Low \\
\hline
\end{tabular}

Analysis of result data presented in the Table 2 showed that academics in Nigerian Polytechnic considered attributed high level desirability for computer profession to graduate attributes: Ability to apply knowledge to solving theoretical and practical problems in other related area in relation to national and societal needs having Mean \& SD scores of 4.321 and 1.562 respectively.

Also, academics reported a low level of desirability to graduate attributes such as: user focused ( $M=1.010 \& S D=1.640)$; Internet surfing skills and Proficiency in social media application with each having Mean $=1.010 \&$ S.D $=1.427$.

\subsection{Research Question 3}

What graduate attributes in computing disciplines do academics of COEs in Nigeria consider desirable to prepare graduates for entry into a computing profession.

Table 3 presents the perceptions of lecturers in Nigerian COEs on graduate attributes in computing disciplines desirable for entry into a computing profession

Table 3 Perceptions of lecturers on Nigerian COEs on graduate attributes in computing disciplines desirable for entry into a computing profession

\begin{tabular}{|c|l|c|c|c|c|c|}
\hline S/N & \multicolumn{1}{|c|}{ Graduate Attributes } & F & N & Mean & S.D & Decision \\
\hline 1 & $\begin{array}{l}\text { Communication effectively using visual, } \\
\text { mathematical and or language skills }\end{array}$ & 43 & 50 & 4.161 & 1.554 & Desirable \\
\hline 2 & $\begin{array}{l}\text { Using and displaying creative thinking for } \\
\text { responsible problem solving }\end{array}$ & 37 & 50 & 3.221 & 1.498 & Desirable \\
\hline 3 & Creativity and innovative thinking & 41 & 50 & 3.955 & 1.551 & Desirable \\
\hline 4 & Leadership quality, collaboration and teamwork & 41 & 50 & 3.955 & 1.552 & Desirable \\
\hline 5 & $\begin{array}{l}\text { Cognitive ability and skills in practical skills } \\
\text { relating to solution of mathematical problems } \\
\text { and its application }\end{array}$ & 47 & 50 & 4.548 & 1.450 & Desirable \\
\hline 6 & Lifelong learning skills & 43 & 50 & 4.161 & 1.555 & Desirable \\
\hline 7 & $\begin{array}{l}\text { Self management of learning development, time } \\
\text { and organizational skills }\end{array}$ & 37 & 50 & 3.512 & 1.498 & Desirable \\
\hline 8 & Teaching skills & 40 & 50 & 3.912 & 1.599 & Desirable \\
\hline
\end{tabular}




\begin{tabular}{|c|c|c|c|c|c|c|}
\hline 9 & $\begin{array}{l}\text { Ability to apply knowledge to solving theoretical } \\
\text { and practical problems in other related area in } \\
\text { relation to national and societal needs }\end{array}$ & 43 & 50 & 4.161 & 1.501 & Desirable \\
\hline 10 & Adaptability and flexibility & 9 & 50 & 1.010 & 1.642 & Low \\
\hline 11 & Internet surfing skills & 11 & 50 & 1.021 & 1.399 & Low \\
\hline 12 & Research skills & 41 & 50 & 3.959 & 1.499 & Desirable \\
\hline 13 & $\begin{array}{l}\text { Attention to rigorous thinking: knowledge and } \\
\text { understanding of modelling and design }\end{array}$ & 33 & 50 & 3.321 & 1.500 & Desirable \\
\hline 14 & $\begin{array}{l}\text { Programming Proficiency in several } \\
\text { programming languages }\end{array}$ & 42 & 50 & 3.99 & 1.087 & Desirable \\
\hline 15 & Analytical thinking & 16 & 50 & 1.23 & 1.490 & Low \\
\hline 16 & Resilient in the face of obstacles & 16 & 50 & 1.23 & 1.491 & Low \\
\hline 17 & I Interpersonal skills & 30 & 50 & 3.013 & 1.297 & Desirable \\
\hline 18 & Organizational skills & 30 & 50 & 3.011 & 1.497 & Desirable \\
\hline 19 & Developing entrepreneurial opportunities & 15 & 50 & 1.193 & 1.498 & Desirable \\
\hline 20 & Capacity to business orientation & 15 & 50 & 1.193 & 1.496 & Desirable \\
\hline 21 & Capacity to future focused & 16 & 50 & 1.230 & 1.447 & Moderate \\
\hline 22 & User focused & 3 & 50 & 0.010 & 1.640 & Low \\
\hline 23 & Attainment to engineering principles & 10 & 50 & 1.003 & 1.498 & Low \\
\hline 24 & Proficiency in social media application & 16 & 50 & 1.230 & 1.427 & Low \\
\hline 25 & Critical evaluation and testing & 16 & 50 & 1.23 & 1.465 & Low \\
\hline
\end{tabular}

Results presented in the Table 3 showed that academics in Nigerian COEs attributed high level desirability for computer profession to graduate attributes: Cognitive ability and skills in practical skills relating to solution of mathematical problems and its application $(\mathrm{M}=4.548 \& \mathrm{SD}=1.45)$; Communication effectively using visual, mathematical and or language skills $(\mathrm{M}=4.161 \& \mathrm{SD}=1.554)$. Other graduate attributes that were perceived to be of high level desirability for computer profession to graduate attributes: Leadership quality, collaboration and teamwork (3.955 \& 1.552); Creativity and innovative thinking (3.955 \& 1.552); Teaching skills (3.912 \& 1.599). However, academics reported a low level of desirability to graduate attributes such as: User focused ( $M=0.01 \&$ SD = 1.64); Adaptability and flexibility (M $=1.01 \& \mathrm{SD}=1.642) ;$ Attainment of engineering principles $(\mathrm{M}=1.003 \& \mathrm{SD}=1.498)$.

\subsection{Research Question 4}

Is there any difference in the graduate attributes desirable for computing profession across the three sectors of HEIs in Nigeria?

Table 4 shows the result of the ANOVA test procedures comparing the mean scores of the identified graduate attributes desirable for entry into computing profession as perceived by lecturers from the three sectors of Nigerian HEIs.

Table 4 ANOVA procedure to compare the mean scores of the graduate attributes perceived by lecturers of the three Nigerian HEIs sectors

\begin{tabular}{|l|c|c|c|c|}
\hline Source of Variation & $\begin{array}{l}\text { Sums of } \\
\text { Squares (SS) }\end{array}$ & $\begin{array}{l}\text { Degree of } \\
\text { Freedom (DF) }\end{array}$ & $\begin{array}{l}\text { Means F } \\
\text { Squares (MS) }\end{array}$ & F \\
\hline Between Treatments & 0.22 & 2 & 0.11 & 0.181 \\
\hline Error (or Residuals) & 13 & 72 & & 0,61 \\
\hline Total & 16.8 & 74 & & \\
\hline
\end{tabular}


The analysis of data in the table (Table 4) showed that $\mathrm{F}=0.61$ and the critical value $=3.12$. Thus, $\mathrm{H}_{0}$ is accepted and alternative hypothesis $\mathrm{H}_{2}$ rejected because $\mathrm{F}<$ critical value.. This result reveals a statistically significant evidence at $\alpha=0.05$ to show that there is no significant difference between the mean scores of the graduate attributes desirable to prepare graduate for entry into computing profession as perceived by lecturers from the three sectors of the Nigerian HEIs.

\section{Discussion and Findings}

Research question 1 asks "What graduate attributes in computing disciplines do academics of Nigeria Universities consider desirable to prepare graduates for entry into a computing profession?" The findings revealed that important graduate attributes in computing discipline such as: Leadership quality, collaboration and teamwork; Cognitive ability and skills in practical skills relating to solution of mathematical problems and its application; Ability to apply knowledge to solving theoretical and practical problems in other related area in relation to national and societal needs; Creativity and innovative thinking; Communication effectively using visual, mathematical and or language skills; Lifelong learning skills, were most desirable graduate attributes in computing discipline that academics in the Nigerian Universities considered for entry computing professions.

Research question 2 asks "What graduate attributes in computing disciplines do academics in Nigeria Polytechnic consider desirable to prepare graduates for entry into computing profession?" The findings show that majority of the graduate attributes that are considered by university lecturers were also considered desirable to prepare competent computer professional by lecturers in Nigerian Polytechnic. However, lecturers in polytechnic attributed higher priority to attributes that have to do with ability and creativity attributes rather than leadership and teamwork attributes. In order words, graduate attributes such as: Ability to apply knowledge to solving theoretical and practical problems in other related area in relation to national and societal needs and Creativity and innovative thinking were amongst the attributes that were considered with higher desirability for entry into computing profession.

Research question 3 asks "What graduate attributes in computing disciplines do academics in Nigerian COEs consider desirable to prepare graduates for entry into computing profession?" The findings show same pattern of considerations between COEs lecturers and their colleagues in other HEIs in Nigeria. However, lecturers in COEs in Nigeria attributed higher level desirability to graduate attributes that are concern with cognitive ability skills, teaching and learning skills, and communication skills for entry into computing profession.

Finally, the null hypothesis designed for the study and used to answer research question 4 says: there is no significant difference between the graduate attributes desirable for entry into computing profession across the three sectors of HEIs desirable for entry into computer profession. The interpretation of this finding revealed that there is no significant difference in the mean score of graduate attributes in computing discipline across the three sectors of Nigerian HEIs as perceived by lecturers from the three sectors of the HEIs.. Thus, there is no significant difference between the graduate attributes desirable for computing profession across the three sectors of HEIs as perceived by lecturers in the education sector.

\section{Recommendations}

The following recommendations are made:

- Graduate attributes for all computing disciplines should be clearly stated in all the Nigerian HEIs that offer the programmes, which will focus on helping prospective graduate in computing related discipline on how information about graduate attributes can prepare prospective graduate in computing discipline for entry into computing profession.

- There is the need to establish career development support centres in all the sectors of HEIs in Nigeria that will help students and prospective graduates become more aware of their career interests and motivate their professional development.

\section{Conclusion}

On the basis of the findings of this study it was concluded that: 
- Graduate attributes that are concerned with leadership and team work are of high priority requirement to university graduate for entry into computing profession, while attributes that are concerned with ability and or cognitive ability, practical and creativity skills are considered top requirements to polytechnic graduates for entry into computing profession. Also, graduate attributes that are concerned with cognitive ability, teaching and learning skills, and communication skills are considered top requirements for COEs graduates for entry into computing professions in Nigeria

- Leadership quality; collaboration and teamwork ability; Effective communication skills; lifelong learning skills; Cognitive ability and practical skills, ability to apply knowledge to solving theoretical and practical problems; Creativity and innovative thinking and time management skills are the most desirable graduate attributes in computing disciplines to prepare graduate for entry into computing profession in Nigeria

- There was no significant difference between the graduate attributes desirable to prepare graduate of computing disciplines from any HIEs in Nigeria for entry into computing discipline

- Another significant conclusion was that computing departments in all HEIs in Nigeria should be aware of the findings of this study use it as tools for assessment and accreditations

\section{Compliance with ethical standards}

\section{Acknowledgments}

We sincerely appreciate the cooperation and active participation of our research participants, the academic staffs in all the participating Higher Education Institutions across the North-Western Nigeria.

We also extend our heartfelt gratitude and appreciation to the Federal Government of Nigeria as the source of the research grant for this research through the Tertiary Education Trust Fund (TETFUND) in Nigeria for the Institution Based Academic Research (IBR) merged - 2017/2019.

\section{Disclosure of conflict of interest}

The authors' conflict of interest revolved around the disparity in the high priority requirement considerations by the three sectors of the HEIs in Nigeria.

Ethical Approval

Ethical Approval granted by the Research and ethics committee of the Federal College of Education (Technical) Gusau Zamfara State Nigeria

\section{References}

[1] ACM/IEEE. Computer Science Curricular: Curriculum Guidelines for Undergraduate Degree Programs. 2013.

[2] ACM/IEEE. IS Curriculum Guidelines for Undergraduate Degree Programs in Information Systems. 2010.

[3] ACM/IEEE. Computing Curricula: The Overview Report. This and the other discipline reports can be found at www.acm.org/education/curricula-recommendations. 2005.

[4] CHE (Council on Higher Education. A Framework for Qualification Standards in Higher Education. Pretoria: Council on Higher Education. [Online]. 2013.

[5] International Engineering Alliance. Graduate Attributes and Professional Competencies. Version 3: 21 June 2013.

[6] Oliver B. Graduate attributes as a focus for institution-wide curriculum renewal: innovations and challenges. Higher Education Research and Development. 2013; 32(3): 450-463.

[7] Odedra M, Lawrie M, Bennett M, Goodman S. Sub-Saharan Africa: A technological desert. Communications of the ACM. 1993; 36(2): 25-29.

[8] International conference on ICT research. Summit on relevant computing in Sub-Saharan Africa. 2010.

[9] Lawal, B.. Introduction to computers for schools and colleges. LP Nigeria 